\section{Open-reading frame (ORF)}

\section{J. Arnemann}

Abteilung Molekulargenetik, Labor Dr. Wisplinghoff, Köln, Deutschland

Synonym(e) Offener Leserahmen; Offenes Leseraster; ORF

Englischer Begriff open reading frame; ORF

Definition Offener Leserahmen bezeichnet in der maturen mRNA den Abschnitt zwischen Start- und Stoppcodon, der im selben Leserahmen liegt und bei einer Translation ohne Unterbrechung in Aminosäuren und damit zu einem Peptid überführt wird.

Beschreibung Bei Eukaryonten umfasst die Transkription eines Gens in eine mature mRNA Bereiche, die in eine Aminosäuresequenz translatiert werden, und welche, die nicht translatiert werden. So werden die flankierend jeweils im 5'und $3^{\prime}$-Bereich der mRNA gelegenen regulatorischen Berei- che, die als 5'-UTR (,untranslated region“) bzw. 3'-UTR definiert sind, nicht in eine Aminosäuresequenz translatiert. Der zwischen diesen UTRs gelegene Abschnitt der mRNA wird vom Startcodon und dem Stoppcodon der Translation begrenzt und als offener Leserahmen für eine Translation bezeichnet. Hier kodieren die Tripletts aneinandergereiht für jeweils eine definierte Aminosäure.

Da es in den Genen, oftmals gewebespezifisch, zur Nutzung alternativer Spleißsignale (alternatives Spleißen) und damit zu einer alternativen Zusammensetzung der mRNA kommt, wird hier auch ein anderer offener Leserahmen generiert mit gegebenenfalls abweichender Aminosäurezusammensetzung.

Abweichend findet man in Prokaryonten häufig polycistronisch mehrere ORFs in einer transkriptionalen Einheit, die als Operon bezeichnet wird.

\section{Literatur}

Knippers R (2001) Molekulare Genetik, 8. Aufl. Thieme Verlag, Stuttgart 